\title{
Effect of some chemicals and essential oil extracts on keeping quality and vase life of cut carnation (Dianthus caryophyllus L.)
}

\author{
Ezz, Thanaa. M(1) B. M. Weheda ${ }^{(2)}$, M. K. Gaber ${ }^{(1)}$ and H.F.K. El-Deeb ${ }^{(3)}$ \\ ${ }^{(1)}$ Plant Production Dept., Faculty of Agriculture (Saba Basha) Alexandria University. \\ (2) Agricultural Research Center, Giza - Egypt. \\ (3) Senior Agricultural Researcher, Agricultural Research Center
}

\begin{abstract}
This experiment was carried out during two successive seasons of (2017 and 201^) on Carnation (Dianthus caryophyllus, L.) cv. "Big Mama" cut flowers at laboratory of the Plant Production Department, Faculty of Agriculture Saba Basha, Alexandria University, to study the effect of some chemicals and essential oil extracts on keeping quality and vase life of carnation cut flowers. Completely randomized block designed experiment with three replicates treatments for each as follow: control (distillated water), Nano-silver thiosulphate (NST) at (2.5, $5,7.5$ and $10 \mathrm{mg} / \mathrm{l})$, Eucalyptus oil at $(25,50$ and $75 \mathrm{mg} / \mathrm{l})$, Mint oil at $(25,50$ and $75 \mathrm{mg} / \mathrm{l})$ and 8-hydroxyquinoline sulphate (8-HQS) at $(250,300,350$ and $400 \mathrm{mg} / \mathrm{l})$. Results showed that Nano-silver thiosulphate (NST) at $10 \mathrm{mg} / \mathrm{l}$ gave the highest mean values of the physical characters as dry weights ( $\mathrm{g}$ ), floret diameter, vase life, and decrease the number of bacteria, also, Nano-silver thiosulphate (NST) at $10 \mathrm{mg} / \mathrm{l}$ gave the best results of chemical compositions as total sugars (\%), reducing sugars (\%), non-reducing sugars (\%),total soluble solids percentage and total carbohydrate percentage as compared with control treatment, which gave the lowest mean values of the all physical and chemical composition during both seasons.
\end{abstract}

Keywords: Carnation (Dianthus caryophyllus L.), preservative solutions, vase life, physical character, chemical composition

\section{INTRODUCTION}

Carnation (Dianthus caryophyllus, L.) belongs to family Caryophyllaceae and is one of the most popular cut flowers in the world. It is native to the Mediterranean region, southern Europe and central Asia (Basiri et al., 2011).

In addition, it is one of the most important flowers in the world wide floriculture commerce, and hundreds of cultivars of carnation are grown everywhere in the world. Dianthus is a genus that has about 300 species of annual, biennial and perennial in the Caryophyllaceae family (Tanase et al., 2012).

Today's commercial carnations are the product of more than 200 years breeding, carnations of present day flower year around, and have a wider color range, large flower size and sturdier stems than their wild families (Sharma et al., 2013).

Vase life is a yardstick for the longevity of cut flowers and is an important target for improving flower characteristics, whether by chemical treatments or by plant breeding. Maintaining good quality of cut flowers and extending the vase life are considered important to meet the consumer preference. Vase life of cut flowers is mainly affected by two main factors, namely ethylene which accelerates the senescence of many flowers, and microorganisms especially fungi and bacteria that grow in the vase solution, block the stem end and limit water uptake by the flowers, besides the production of chemical compounds that cause vascular blockage and thus reducing the vase life of cut flowers (Hashemabadi et al., 2015). Cut flowers are short-lived and are prone to rapid 
deterioration. Shortening vase life of cut flowers could be attributed to destruction of the transport vessels of the stem after cutting, hence, the inability of the stem to absorb water due to blockage may be leading to excessive water loss and short supply of carbohydrates to support respiration. It has been stated that microbial contamination, the cause of vascular occlusion, is the most limiting factor in longevity of cut flowers (Kazemi et al., 2011). Thus, with the aim of promoting the vase life of cut flowers, chemicals with antimicrobial effects such as silver nitrate, aluminium sulphate and 8-hydroxyquinoline sulphate, have been applied in vase solutions (Lv et al., 2010).

Nowadays with respect to the high competition in the market, there is more concern about postharvest life of cut flowers. It is obvious that cut flowers are facing wounding, water deficit, microbial contamination and oxidative stresses during the postharvest life. According to the scientific findings, the postharvest life of different ornamental cut flowers could be affected by the application of various chemicals as preservatives (Prashanth et al., 2010; Danaee et al., 2013 and Ardebili et al., 2013). The use of chemicals as the most primitive method of controlling postharvest diseases has been limited because of carcinogenesis, long-term degradation, pollution and their effects on food (such as toxicity and the induction of bad smells), human health, it is better to identify and use natural alternatives to extend the vase life of cut flowers and to ensure the health of products, as well as the health of buyers and sellers (Khosravi et al., 2015). Silver nanoparticles represent one of the most extensively studied nanomaterial's, which have fascinated scientists due to their unique optical, catalytic, sensing and antimicrobial properties (Wu et al., 2012). Silver nanoparticles are especially attractive for their antimicrobial sterilization features among the nanoparticles (Solgi, 2014). Because of their high surface area to volume ratio, nanometer-sized silver $\left(\mathrm{Ag}^{+}\right)$particles (NS) are considered to inhibit bacteria and other microorganisms more strongly than $\mathrm{Ag}$ in various oxidation states, $\mathrm{Ag}, \mathrm{Ag}^{+}, \mathrm{Ag}^{2+}, \mathrm{Ag}^{3+}$ (Furno et al., 2004).

Herbal essential oils are natural compounds that are known as secondary metabolites which have powerful effect on pathogens control and their antimicrobial impact is proven as well. These compounds increases the vase life of cut flowers and their use is becoming widespread recently (Sharififar et al., 2007 and Svircev et al., 2007). The application of 8-HQS increased the vase life as well as the fresh weight (percentage of initial) of the cut flowers, whereas 8-HQS treatment prevented growth of the microorganisms in xylem vessels of the cut flower stems and maintained water uptake. However, the 8HQS treatment was more effective when sucrose was coupled with it (Pun and Ichimura, 2003).The aim of the present study was to: 1) extend the vase life and keeping quality of Carnation (Dianthus caryophyllus L.) cut flowers by using different pulsing and holding solutions, 2) compare the effect of the used pulsing, holding solutions with essential oils and nano Silver thiosulfate on prolonging vase life of Carnation cut flowers, and 3) determining the best concentration of the above mentioned solutions to achieve the longest vase life. 


\section{MATERIALS AND METHODS}

Two separate experiments were conducted in the Plant Production Department, Faculty of Agriculture, Saba Basha, Alexandria University in January, 2017 and 2018 on Carnation (Dianthus caryophyllus L. cv. Big) Mama cut flowers to study the effect of some chemicals and essential oil extracts on keeping quality and vase life of carnation cut flowers. The experiment lasted one month.

\section{Cut flowers materials and preparation}

The cut flowers used for this investigation, Carnation (Dianthus caryophyllus, L. cv. "Big Mama") were obtained from a well-known commercial nursery in Alexandria. Cut flowers were cut from the field in early morning after harvested wrapped with polyethylene sheet, and then quickly moved to the experiment room, of an average temperature of $\left(19^{\circ} \pm 1^{\circ} \mathrm{C}\right)$ for first and second experiments and light from a white fluorescent lamp for 12 hours.

\section{Experimental Design}

The experiment was designed as completely randomized design with three replicates.

The treatments were conducted as follows:

- Control

- Nano-silver $(2.5,5,7.5$ and $10 \mathrm{mg} / \mathrm{l})$

- Eucalyptus oil $(25,50$ and $75 \mathrm{mg} / \mathrm{l})$

- Mint oil (25, 50 and $75 \mathrm{mg} / \mathrm{l})$

- 8 hydroxyqunon $(250,300,350$ and $400 \mathrm{mg} / \mathrm{l})$

\section{Nano-silver thiosulphate (NST)}

1) Dissolve $0.079 \mathrm{~g} \mathrm{AgNO}_{3}$ in $500 \mathrm{ml}$ of deionized water

2) Dissolve $0.462 \mathrm{~g} \mathrm{~N}_{2} \mathrm{~S}_{2} \mathrm{O}_{3}-\mathrm{H}_{2} \mathrm{O}$ in $500 \mathrm{ml}$ of deionized water

3) Pour $\mathrm{AgNO}_{3}$ solution into $\mathrm{N}_{2} \mathrm{~S}_{2} \mathrm{O}_{3}-5 \mathrm{H}_{2} \mathrm{O}$ solution while stirring

The concentration of silver nanoparticles is $0.463 \mathrm{ml} / \mathrm{l}$.

The silver thiosulfate (STS) prepared as described by Gorin et al. (1989).

\section{Pulsing solutions}

The flowers were given pre-treatments of pulsing solutions which freshly prepared at the start of experiments from (different concentrations of eucalyptus oil and mint 1 Liter of distilled water contained $1 \%$ sucrose) in containers for 24 hours.

\section{Holding solutions}

The flowers were moved to glass containers (vases) which contained 300 $\mathrm{ml}$ of distilled water to calculate the vase life and the tested parameters. The water in the vases replacement and also about $1 \mathrm{~cm}$ of the stems was cut every 3 days. Vases were exposed every day at night to light from a white fluorescent lamp for 12 hours and during the day were exposed to daylight. The room temperature was about $\left(19^{\circ} \pm 1^{\circ} \mathrm{C}\right)$ for the first and the second experiments. 


\section{Data recorded}

The collected data was:

A) Physical characters:

- Total dry weight $(\mathrm{g})$.

- Vase life (days).

- Bacterial counts (colonies/ ml)

- Flower diameter $(\mathrm{cm})$

\section{B) Chemical analysis}

- Total soluble solids (TSS \%): in the extracted juice of carnation petals were measured by a hand refractometer (Brix $\% 20^{\circ} \mathrm{C}$ ) as reported by Lacey et al. (2001).

- Total carbohydrates (\%): were determined in the stems and petals of the best treatment of the two compounds. Samples were taken on day 1, 3 and 5 and separated by a high performance liquid chromatography (HPLC) fitted with a differential refractometer to detect fructose, glucose and sucrose in the different samples (Moon-Soo et al., 2001).

- Total sugars content in flowers (\%):

It was calculated in dry flowers at the beginning and every 4 days, sugars were extracted from five grams of flowers, the total sugars were determined colorimetrically using phenol and sulphuric acid according to (Malik and Singh, 1980).

- Reducing sugar (\%) were determined by Nelson arsenate - molybdate colorimetric method (Dubois et al., 1956).

- Non-reducing sugar (\%) were calculated by the difference between total sugars and reducing sugar.

\section{Statistical analysis}

All the data collected were subjected to statistical analysis of variance as described by Gomez and Gomez (1984). The treatment means were compared using L.S.D. test at 0.05 level of significant.

\section{RESULTS AND DISCUSSION}

\section{A) Physical characters}

The effect of some chemicals and essential oil extracts on dry weight $(\mathrm{g})$, vase life period (days) and bacterial counts (colonies/ ml) of carnation (Dianthus caryophyllus L.) cv. "Big Mama" cut flowers are presented in Table (1). Results showed that applied concentrations of nano-silver at $10 \mathrm{mg} / \mathrm{l}$ recorded the maximum values of dry weight $(15.39$ and $16.92 \mathrm{~g})$, followed by eucalyptus oil at $75 \mathrm{mg} / \mathrm{l}$ (14.31 and $15.73 \mathrm{~g}), 8$ - hydroxyqunon at $350 \mathrm{mg} / \mathrm{l}(13.51$ and 16.50 g) and mint oil at $75 \mathrm{mg} / \mathrm{l}(13.52$ and $14.90 \mathrm{~g})$, during both seasons, respectively, as compared with the control treatment which recorded the minimum values of dry weight (10.09 and $11.09 \mathrm{~g})$.

The chemical solutions of 8 -HQS at 100 or $200 \mathrm{mg} / \mathrm{l}$ with $4 \%$ sucrose lowered the flower weight loss and increased dry weight percentage and longevity of cut flowers to highest values and also resulted in the highest 
soluble sugars and anthocyanin pigment in petals of flowers (Ibrahim et al., 2011). Also, Banaee et al. (2013) reported that 8-HQS increased vase life, dry weight, wet weight, flower diameter, mean absorbed preservative solution, and quality score.

This may be due to the role of sucrose in providing the required energy for survival of flowers and affecting the structure of the flower cell walls and delays aging through this and causing an increase in the dry weight and water retention. Compounds extending the vase life of cut flowers on the prevention of dry weight loss by preventing the degradation of carbohydrates (Dashtbany and Hashemabadi, 2015).

On the other sides, the best result in this regard was obtained from the treatment of 8 - hydroxyqunon at $400 \mathrm{mg} / \mathrm{l}$ (28.65 days) which was effective in extending vase life period in the first season and 8 - hydroxyqunon at $\mathrm{ro} \cdot \mathrm{mg} / \mathrm{l}$ (31.69 days) in the second one, followed by the treatment of $10 \mathrm{mg} / \mathrm{I}$ nanosilver (28.42 and 31.25 days), eucalyptus oil at $75 \mathrm{mg} / \mathrm{l}(25.02$ and 27.52 days), and mint oil at $75 \mathrm{mg} / \mathrm{l}$ (24.25 and 26.67 days) during both seasons, respectively, as compared with the control treatment (19.57 and 21.52 days).

Similar effect was obtained by nano-silver at $10 \mathrm{mg} / \mathrm{l}$ which due enhanced shelf life of the cut flowers compared to the control. This may be due to the positive effect of NS treatments to inhibit bacterial growth in the vase solution and at the cut surface stems during shelf life period. The fresh weight of cut flowers diminished as they approach the aging step. This may be related to the reduction of water absorption and the loss through petals and leaves turgidity. The current findings support this idea, Hashemabadi (2014) and Basiri et al. (2011) showed that the silver nano-particles treatment inhibited bacterial growth in the preservative solution and enhanced vase life of cut carnation. Many authors indicated the role of NS in prolonging shelf life of cut flowers as confirmed by Liu et al. (2009) and Solgi et al. (2009) on gerbera cultivars, Lü et al. (2010) and Hatami et al. (2013) on rose and Roshani et al. (2016) on cut carnation.

Due to the huge side-effects of chemicals, essential oils have been considered as suitable alternatives for keeping the vase-life of cut flowers mainly owing to the availability and environment-friend nature of these biochemicals (Ebrahimzadeh et al., 2017).

On the other hand, from the recorded data in Table (1), it can be concluded that treatment of $10 \mathrm{mg} /$ I nano-silver recorded a decrease in number of bacteria (22.91and 24.80), followed by $7.5 \mathrm{mg} / \mathrm{l}$ nano-silver (25.06 and 27.56 ) in the two seasons of experiment, as well as, 8-hydroxyqunon at $350 \mathrm{mg} / \mathrm{l}$ (24.06) in the first season and 8-hydroxyqunon at $400 \mathrm{mg} / \mathrm{l}$ (27.29) in the second season, respectively, in vase solution as compared to other treatments under study and control. Such increase was highly significant with the two seasons. On the other side, the maximum average of bacterial count was recorded by control treatment $(61.87,77.33,68.05,85.07)$ in the first and second seasons, respectively. 
In accordance with the previous gains, Furno et al. (2004) affirmed that silver nanoparticle (SNP) as a pulse treatment for cut flowers has demonstrated importance as an anti-bactericidal agent that could kill 650 species of bacteria in water. It seems to get be some benefit in reducing bacteria from using 8-HQC at $400 \mathrm{mg} / \mathrm{l}$ but gerbera flowers showed a phenomenon of stem damage (stem under the water solution became brown after just 1 or 2 days), and the toxicity of $8-\mathrm{HQC}$ for other gerbera variety was discovered in previous study as well (De Witte et al., 2014).

Some researchers reported that essential oil components attack cell wall and react with enzymes responsible for synthesis of cell wall and as a result causing pathogen death (Sharma and Tripathi, 2008). 
Table (1). Effect of some chemicals and essential oil extracts on dry weight (g), vase life (days) and bacterial counts (colonies/ ml) of Dianthus caryophyllus, L. cv. "Big Mama" during 2017 and 2018 seasons

\begin{tabular}{|c|c|c|c|c|c|c|}
\hline \multirow{3}{*}{ Treatments } & \multicolumn{2}{|c|}{ Dry weight (g) } & \multicolumn{2}{|c|}{ Vase life (days) } & \multicolumn{2}{|c|}{ Bacterial counts (colonies/ ml) } \\
\hline & \multirow{2}{*}{$\begin{array}{c}2017 \\
\text { season }\end{array}$} & \multirow{2}{*}{$\begin{array}{c}2018 \\
\text { season }\end{array}$} & \multirow{2}{*}{$\begin{array}{c}2017 \\
\text { season }\end{array}$} & \multirow{2}{*}{$\begin{array}{c}2018 \\
\text { season }\end{array}$} & After 15 days & After 25 days \\
\hline & & & & & $5 d$ & $15 d$ \\
\hline Control & $10.09^{j}$ & $11.09^{h}$ & $19.57^{9}$ & $21.52^{\mathrm{g}}$ & $61.87^{\mathrm{a}}$ & $77.33^{\mathrm{a}}$ \\
\hline Nano-silver $2.5 \mathrm{mg} / \mathrm{l}$ & $11.22^{\mathrm{i}}$ & $12.33^{\mathrm{g}}$ & $20.71^{f}$ & $22.45^{\mathrm{fg}}$ & $30.95^{\mathrm{fg}}$ & $39.02^{\mathrm{fg}}$ \\
\hline Nano-silver $5 \mathrm{mg} / \mathrm{l}$ & $12.79^{f}$ & $13.71^{f}$ & $23.01^{d}$ & $25.31^{d}$ & $27.85^{\mathrm{h}}$ & $35.11^{\mathrm{h}}$ \\
\hline Nano-silver $7.5 \mathrm{mg} / \mathrm{l}$ & $13.85^{d}$ & $15.22^{\mathrm{cd}}$ & $25.57^{b}$ & $28.13^{b}$ & $25.06^{i}$ & $31.60^{i}$ \\
\hline Nano-silver 10 mg/l & $15.39^{a}$ & $16.92^{\mathrm{a}}$ & $28.42^{\mathrm{a}}$ & $31.25^{\mathrm{a}}$ & $22.91^{i}$ & $28.44^{\mathrm{j}}$ \\
\hline Eucalyptus 25 mg/l & $11.58^{\mathrm{h}}$ & $13.74^{f}$ & $20.26^{f}$ & $22.28 \mathrm{~g}$ & $37.48^{\mathrm{C}}$ & $46.89^{\mathrm{C}}$ \\
\hline Eucalyptus $50 \mathrm{mg} / \mathrm{l}$ & $12.87^{\dagger}$ & $14.15^{\mathrm{ef}}$ & $22.51^{\text {de }}$ & $24.76^{\mathrm{de}}$ & $33.73^{\mathrm{e}}$ & $42.17^{\mathrm{e}}$ \\
\hline Eucalyptus $75 \mathrm{mg} / \mathrm{l}$ & $14.31^{\mathrm{c}}$ & $15.73^{\mathrm{bc}}$ & $25.02^{b}$ & $27.52^{\mathrm{bc}}$ & $30.36^{\mathrm{g}}$ & $37.95^{\mathrm{g}}$ \\
\hline Mint $25 \mathrm{mg} / \mathrm{l}$ & $10.97^{i}$ & $11.86^{\mathrm{gh}}$ & $19.64^{g}$ & $21.60^{\mathrm{g}}$ & $39.34^{b}$ & $49.17^{\mathrm{b}}$ \\
\hline Mint $50 \mathrm{mg} / \mathrm{l}$ & $12.19^{\mathrm{g}}$ & $13.41^{f}$ & $21.82^{\mathrm{e}}$ & $24.00^{\mathrm{e}}$ & $35.40^{\mathrm{d}}$ & $44.5^{\mathrm{d}}$ \\
\hline Mint $75 \mathrm{mg} / \mathrm{l}$ & $13.52^{\text {de }}$ & $14.90^{\text {de }}$ & $24.25^{\mathrm{c}}$ & $26.67^{\mathrm{c}}$ & $31.86^{f}$ & $39.83^{f}$ \\
\hline 8-hydroxyqunon $250 \mathrm{mg} / \mathrm{l}$ & $10.94^{i}$ & $13.36^{f}$ & $20.88^{f}$ & $25.52^{d}$ & $34.17^{\text {de }}$ & $42.72^{\mathrm{e}}$ \\
\hline 8-hydroxyqunon $300 \mathrm{mg} / \mathrm{l}$ & $12.16^{\mathrm{g}}$ & $14.85^{\mathrm{de}}$ & $23.21^{\mathrm{d}}$ & $28.36^{\mathrm{b}}$ & $30.76^{\mathrm{fg}}$ & $38.44^{\mathrm{fg}}$ \\
\hline 8-hydroxyqunon $350 \mathrm{mg} / \mathrm{l}$ & $13.51^{\mathrm{e}}$ & $16.50^{\mathrm{ab}}$ & $25.45^{\mathrm{b}}$ & $31.69^{a}$ & $24.06^{i}$ & $31.14^{i}$ \\
\hline 8-hydroxyqunon $400 \mathrm{mg} / \mathrm{l}$ & $15.01^{b}$ & $12.03^{\mathrm{g}}$ & $28.65^{\mathrm{a}}$ & $22.97^{\dagger}$ & $27.68^{h}$ & $34.60^{\mathrm{h}}$ \\
\hline LSD (0.05) & 0.33 & 0.80 & 0.84 & 0.97 & 1.34 & 1.41 \\
\hline
\end{tabular}


Data presented in Table (2) showed that all treatments with different concentrations promoted flower diameter of carnation cut flower. Treatment of $10 \mathrm{mg} / \mathrm{l}$ nano-silver thiosulphate gave the biggest carnation florets diameter $(13.79$ and $13.48 \mathrm{~cm})$, followed by $7.5 \mathrm{mg} / \mathrm{l}$ nano-silver $(12.41$ and $12.13 \mathrm{~cm}$ ) and 8-hydroxyqunon at $350 \mathrm{mg} / \mathrm{l}(12.28$ and $12.36 \mathrm{~cm})$, respectively, as compared with the other treatments under study and control.

In harmony to the present results, Ichimura et al. (2002) showed that an increase in flower diameter was observed when $20 \mathrm{~g}$ of sucrose/L $+200 \mathrm{mg}$ of $\mathrm{HQS} / \mathrm{L}$ were used in the pulsing solution.

Meanwhile, the Rosemary essential oil significantly increased the flower diameter. The study results of Karimi et al. (2011) showed that the treatments of 600 and $800 \mathrm{mgl}^{-1}$. Rosemary essential oil increased the cut rose diameter that is consistent with their study. 
Table (2). Effect of some chemicals and essential oil extracts on flower diameter (cm) of Dianthus caryophyllus, L. cv. "Big Mama" during 2017 and 2018 seasons

\begin{tabular}{|c|c|c|c|c|c|c|c|c|c|c|}
\hline \multirow{3}{*}{ Treatments } & \multicolumn{10}{|c|}{ Floret diameter (cm) } \\
\hline & \multicolumn{5}{|c|}{2017 season } & \multicolumn{5}{|c|}{2018 season } \\
\hline & 0 & $5 d$ & 10d & 15d & 20d & 0 & $5 d$ & 10d & 15d & 20d \\
\hline Control & $8.61^{\mathrm{e}}$ & $9.04 \mathrm{e}$ & $7.72 \mathrm{e}$ & $6.17 e$ & $4.94^{\mathrm{tgh}}$ & $8.74^{\mathrm{tg}}$ & $8.84^{h}$ & $7.60^{h}$ & $6.08^{h}$ & $4.86^{i j}$ \\
\hline Nano-silver 2.5 mg/l & $9.57^{d}$ & $10.05 d$ & $8.58 d$ & $6.86 d$ & $5.49^{\text {efd }}$ & $9.72^{\mathrm{de}}$ & $9.82^{f}$ & $8.45^{\dagger}$ & $6.75^{f}$ & $5.40^{\mathrm{fgh}}$ \\
\hline Nano-silver 5 mg/l & $10.63^{c}$ & $11.17 \mathrm{c}$ & $9.53 c$ & $7.62 \mathrm{c}$ & $6.10^{\mathrm{bcd}}$ & $10.80^{c}$ & $10.91^{d}$ & $9.38^{d}$ & $7.50^{\mathrm{d}}$ & $6.20^{\text {cde }}$ \\
\hline Nano-silver 7.5 mg/l & $11.81^{\mathrm{b}}$ & $12.41 \mathrm{~b}$ & $10.59 \mathrm{~b}$ & $8.47 b$ & $6.78^{\mathrm{b}}$ & $11.99^{b}$ & $12.13^{b}$ & $10.43^{b}$ & $8.34^{b}$ & $6.67^{\mathrm{bc}}$ \\
\hline Nano-silver 10 mg/l & $13.13^{a}$ & $13.79 a$ & $11.77 a$ & $9.41 \mathrm{a}$ & $7.53^{\mathrm{a}}$ & $13.33^{\mathrm{a}}$ & $13.48^{a}$ & $11.59^{\mathrm{a}}$ & $9.27^{\mathrm{a}}$ & $7.41^{a}$ \\
\hline Eucalyptus 25 mg/l & $8.94^{\mathrm{e}}$ & $9.38 \mathrm{e}$ & $7.97 \mathrm{e}$ & $6.38 \mathrm{e}$ & $5.57^{\text {cdef }}$ & $8.94^{f}$ & $9.38^{9}$ & $8.06^{9}$ & $6.45^{\mathrm{g}}$ & $5.82^{\mathrm{ef}}$ \\
\hline Eucalyptus $50 \mathrm{mg} / \mathrm{l}$ & $9.93^{d}$ & $10.42 d$ & $8.86 d$ & $7.09 d$ & $5.45^{\mathrm{def}}$ & $9.95^{d}$ & $10.42^{\mathrm{e}}$ & $8.96^{\mathrm{e}}$ & $7.17^{\mathrm{e}}$ & $5.73^{\mathrm{ef}}$ \\
\hline Eucalyptus $75 \mathrm{mg} / \mathrm{l}$ & $10.03^{c}$ & $11.58 c$ & $9.85 \mathrm{c}$ & $7.87 \mathrm{c}$ & $6.30^{\mathrm{bc}}$ & $11.06^{\mathrm{c}}$ & $11.58^{\mathrm{c}}$ & $9.96^{c}$ & $7.96^{\mathrm{c}}$ & $6.37^{\mathrm{bcd}}$ \\
\hline Mint 25 mg/l & $8.06^{\dagger}$ & $8.47 f$ & $7.18 f$ & $5.75 f$ & $4.43^{\mathrm{h}}$ & $7.63 \mathrm{~h}$ & $8.47^{i}$ & $7.28^{i}$ & $5.82^{i}$ & $4.65^{\mathrm{j}}$ \\
\hline Mint 50 mg/l & $8.96 \mathrm{e}$ & $9.41 \mathrm{e}$ & $7.99 \mathrm{e}$ & $6.39 \mathrm{e}$ & $4.92^{\text {fgh }}$ & $8.47^{\mathrm{g}}$ & $9.41^{\mathrm{g}}$ & $8.09^{9}$ & $6.47^{\mathrm{g}}$ & $5.17^{\mathrm{ghi}}$ \\
\hline Mint 75 mg/l & $9.96^{d}$ & $10.45 d$ & $8.88 d$ & $7.10 \mathrm{~d}$ & $5.68^{\text {cde }}$ & $9.42^{\mathrm{e}}$ & $10.45^{\mathrm{e}}$ & $8.99^{e}$ & $7.17^{\mathrm{e}}$ & $5.75^{\mathrm{ef}}$ \\
\hline 8-hydroxyqunon 250 mg/l & $8.58^{\mathrm{e}}$ & $9.01 \mathrm{e}$ & $7.66 \mathrm{ef}$ & $6.12 \mathrm{e}$ & $4.72^{g h}$ & $9.77^{\mathrm{de}}$ & $10.01^{f}$ & $8.61^{\dagger}$ & $6.88^{f}$ & $5.50^{\mathrm{fg}}$ \\
\hline 8-hydroxyqunon $300 \mathrm{mg} / \mathrm{l}$ & $9.54^{d}$ & $10.01 d$ & $8.51 d$ & $6.81 d$ & $5.24^{\text {def }}$ & $10.86 c$ & $11.13^{\mathrm{d}}$ & $9.57^{d}$ & $7.65^{\mathrm{d}}$ & $6.12^{\mathrm{de}}$ \\
\hline 8-hydroxyqunon $350 \mathrm{mg} / \mathrm{l}$ & $11.77^{b}$ & $12.28 \mathrm{~b}$ & $10.51 \mathrm{~b}$ & $8.41 \mathrm{~b}$ & $6.72^{b}$ & $12.07^{b}$ & $12.36^{\mathrm{b}}$ & $10.63^{b}$ & $8.50^{b}$ & $6.80^{\mathrm{b}}$ \\
\hline 8-hydroxyqunon $400 \mathrm{mg} / \mathrm{l}$ & $10.59^{\mathrm{C}}$ & $11.12 \mathrm{c}$ & $9.46 c$ & $7.56 \mathrm{c}$ & $5.83^{\text {cde }}$ & $8.80^{\mathrm{fg}}$ & $9.01^{\mathrm{h}}$ & $7.74^{\mathrm{h}}$ & $6.19^{\mathrm{h}}$ & $4.95^{\text {hij }}$ \\
\hline $\operatorname{LSD}(0.05)$ & 0.48 & 0.52 & 0.48 & 0.38 & 0.73 & 0.41 & 0.28 & 0.24 & 0.19 & 0.49 \\
\hline
\end{tabular}




\section{B) Chemical analysis}

Data in Table (3) illustrate that the most successful treatment was nano silver thiosulphate at $10 \mathrm{mg} / \mathrm{l}$ as it achieved the maximum values of total sugars percentage of carnation cut flowers (2.30 and $2.53 \%$ ), followed by 8-hydroxyqunon at $350 \mathrm{mg} / \mathrm{l}$ (2.11 and $1.69 \%$ ), eucalyptus oil at $75 \mathrm{mg} / \mathrm{l}(1.91$ and $2.10 \%)$ and mint oil at $75 \mathrm{mg} / \mathrm{l}$ (1.82 and $2.00 \%$ ), during both seasons, respectively, as compared with the control treatment (1.60 and $1.76 \%$ ). Also, data represented in Table (3) exhibited that nano silver thiosulphate at $10 \mathrm{mg} / \mathrm{l}$ had significantly the highest values of reducing sugars percentage (1.30 and $1.43 \%$ ), followed by eucalyptus oil at $75 \mathrm{mg} / \mathrm{l}(1.26$ and 1.38 $\%)$, nano silver thiosulphate at $7.5 \mathrm{mg} / \mathrm{I}(1.17$ and $1.28 \%), 8$-hydroxyqunon at 350 $\mathrm{mg} / \mathrm{l}(1.17$ and $0.97 \%)$ and mint oil at $75 \mathrm{mg} / \mathrm{l}(1.02$ and $1.13 \%)$, during both seasons, respectively, as compared with the control treatment $(0.78$ and $0.85 \%)$.

In the other hand, the results tabulated in Table (3) revealed that holding solution contained $10 \mathrm{mg} / \mathrm{I}$ nano silver thiosulphate highly significantly increased non-reducing sugars percentage (1.00 and $1.09 \%$ ), followed by 8 -hydroxyqunon at $350 \mathrm{mg} / \mathrm{l}(0.94$ and $0.74 \%)$ and nano silver thiosulphate at $7.5 \mathrm{mg} / \mathrm{l}(0.92$ and 0.98 $\%)$ during both seasons, respectively, as compared with the control treatment $(0.82$ and $0.94 \%$ ). Elgimabi (2014) mentioned that the combination of sucrose $7 \%+\mathrm{AgNO}_{3}$ $30 \%$ was significantly superior to the rest of combinations in retarding the chlorophyll as well as the carbohydrate degradation of Rosa damascena. Prashant et al. (2010) cited that the translocate sugars accumulated in the flowers increase the osmotic concentration and improve the sugar (total and reducing sugars) concentration and maintain turgidity.

According to data presented in Table (4), flowers treated with $10 \mathrm{mg} / \mathrm{l}$ nano silver thiosulphate significantly increased total soluble solids percentage (12.93 and $13.10 \%$ ), followed by 8-hydroxyqunon at $350 \mathrm{mg} / \mathrm{l}(12.03$ and $12.20 \%)$, nano silver thiosulphate at $7.5 \mathrm{mg} / \mathrm{I}(11.64$ and $11.79 \%)$, eucalyptus oil at $75 \mathrm{mg} / \mathrm{l}(11.13$ and $11.28 \%$ ), and mint oil at $75 \mathrm{mg} / \mathrm{l}(10.47$ and $10.60 \%)$, during both seasons, respectively, as compared with the control treatment (8.48 and $8.59 \%)$. In contrast, Moradi et al. (2012) reported that application of $4 \mathrm{mg} / \mathrm{l}$ nano silver thiosulphate with $3 \%$ sucrose resulted in the highest amount of TSS in cut carnation 'Cream Viana'. It seems that due to the antibacterial activity of thymol and therefore less occlusion of vessels, the absorption of sucrose was performed better via the vase solution which can be a reason to the increase of petals total soluble solids compared to the control. In a study, the use of $100 \mathrm{mgl}^{-1}$ thyme essential oil with $1 \%$ sucrose led to the increase of the Alstroemeria's petals total soluble solids (Mir Saeed Ghazi et al., 2013). Also, data presented in Table (4), flowers treated with $10 \mathrm{mg} / \mathrm{l}$ nano silver thiosulphate significantly increased total carbohydrate percentage (5.65 and $6.92 \%)$, followed by nano silver at $7.5 \mathrm{mg} / \mathrm{I}$ (5.42 and $6.22 \%)$ and 8-hydroxyqunon at 350 $\mathrm{mg} / \mathrm{l}(5.01$ and $5.60 \%)$, during both seasons, respectively, as compared with the control treatment $(3.71$ and $5.09 \%)$. This result was consistent with the observation of Van Doorn (2004) who found that petal carbohydrate contents are one of the most crucial factors influencing the postharvest life of cut flowers. It is proposed that there is a positive correlation between the levels of endogenous sugars and the time to petal wilting. In addition, the senescence process of cut flowers is regulated by phytohormones and correlated with the carbohydrate status of the petals. 
Table (3). Total sugars, reducing sugars and non-reducing sugars (\%) as affected by some chemicals and essential oil extracts on carnation cv. "Big Mama" cultivars during 2017 and 2018 seasons

\begin{tabular}{|c|c|c|c|c|c|c|c|c|c|c|c|c|c|c|c|c|c|c|}
\hline \multirow{3}{*}{ Treatments } & \multicolumn{6}{|c|}{ Total sugars (\%) } & \multicolumn{6}{|c|}{ Reducing sugars (\%) } & \multicolumn{6}{|c|}{ Non-reducing sugars (\%) } \\
\hline & \multicolumn{3}{|c|}{2017 season } & \multicolumn{3}{|c|}{2018 season } & \multicolumn{3}{|c|}{2017 season } & \multicolumn{3}{|c|}{2018 season } & \multicolumn{3}{|c|}{2017 season } & \multicolumn{3}{|c|}{2018 season } \\
\hline & $5 d$ & $10 d$ & $15 d$ & $5 d$ & $10 d$ & $15 d$ & $5 d$ & $10 d$ & $15 d$ & $5 d$ & $10 d$ & $15 d$ & $5 d$ & $10 d$ & $15 d$ & $5 d$ & $10 d$ & $15 d$ \\
\hline Control & $0.91^{\text {ef }}$ & $1.32^{\mathrm{fg}}$ & $1.60^{\mathrm{gh}}$ & $0.99^{\text {fg }}$ & $1.44^{d}$ & $1.76^{\mathrm{gh}}$ & $0.43^{f}$ & $0.62^{f}$ & $0.78^{9}$ & $0.49^{i}$ & $0.68^{\mathrm{fg}}$ & $0.85^{\mathrm{gh}}$ & $0.46^{b c}$ & $0.66^{b c}$ & $0.82^{c}$ & $0.47^{\mathrm{c}}$ & $0.72^{b c}$ & $0.94^{\mathrm{b}}$ \\
\hline $\begin{array}{c}\text { Nano-silver } 2.5 \\
\mathrm{mg} / \mathrm{l}\end{array}$ & $0.94^{\mathrm{e}}$ & $1.34^{\mathrm{ef}}$ & $1.67^{\mathrm{ef}}$ & $1.02^{\mathrm{ef}}$ & $1.47^{\mathrm{d}}$ & $1.84^{\mathrm{ef}}$ & $0.52^{d}$ & $0.75^{d}$ & $0.95^{\text {cdefg }}$ & $0.58^{\mathrm{fg}}$ & $0.82^{d}$ & $1.04^{\mathrm{de}}$ & $0.40^{d c}$ & $0.57^{\mathrm{cd}}$ & $0.72^{\text {def }}$ & $0.44^{\mathrm{cd}}$ & $0.63^{\mathrm{cd}}$ & $0.79^{b c}$ \\
\hline Nano-silver 5 mg/l & $1.08^{c}$ & $1.49^{\mathrm{cd}}$ & $1.86^{\mathrm{cd}}$ & $1.14^{\mathrm{cd}}$ & $1.63^{c}$ & $2.04^{\mathrm{cd}}$ & $0.58^{c}$ & $0.84^{c}$ & $1.05^{\text {bcde }}$ & $0.64^{\mathrm{de}}$ & $0.92^{c}$ & $1.16^{\mathrm{c}}$ & $0.44^{b c}$ & $0.64^{b c}$ & $0.80^{\text {cd }}$ & $0.49^{b c}$ & $0.70^{\mathrm{bc}}$ & $0.88^{\mathrm{bc}}$ \\
\hline $\begin{array}{c}\text { Nano-silver } 7.5 \\
\text { mg/l }\end{array}$ & $1.16^{b}$ & $1.65^{b}$ & $2.07^{b}$ & $1.27^{b}$ & $1.84^{\mathrm{b}}$ & $2.27^{b}$ & $0.64^{b}$ & $0.93^{b}$ & $1.17^{\mathrm{abc}}$ & $0.72^{\mathrm{bc}}$ & $1.02^{b}$ & $1.28^{\mathrm{b}}$ & $0.50^{\mathrm{ab}}$ & $0.71^{\mathrm{ab}}$ & $0.92^{\mathrm{ab}}$ & $0.55^{b}$ & $0.78^{a b}$ & $0.98^{\mathrm{b}}$ \\
\hline $\begin{array}{l}\text { Nano-silver } 10 \\
\mathrm{mg} / \mathrm{l}\end{array}$ & $1.29^{a}$ & $1.84^{\mathrm{a}}$ & $2.30^{\mathrm{a}}$ & $1.41^{\mathrm{a}}$ & $2.02^{\mathrm{a}}$ & $2.53^{\mathrm{a}}$ & $0.72^{\mathrm{a}}$ & $1.04^{\mathrm{a}}$ & $1.30^{\mathrm{a}}$ & & $1.14^{\mathrm{a}}$ & & $0.56^{a}$ & & & $0.61^{a}$ & $0.88^{\mathrm{a}}$ & $1.09^{\mathrm{a}}$ \\
\hline Eucalyptus 25 mg/l & $0.86^{\mathrm{fg}}$ & $1.24^{\text {gh }}$ & $1.55^{\mathrm{hi}}$ & $0.95^{\text {gh }}$ & $1.36^{\text {ef }}$ & $1.70^{h}$ & $0.57^{c}$ & $0.81^{\mathrm{c}}$ & $1.02^{\text {cdef }}$ & $0.62^{e f}$ & $0.89^{c}$ & $1.11^{\mathrm{cd}}$ & $0.29^{f}$ & $0.42^{f}$ & $0.53^{h}$ & $0.32^{\mathrm{fg}}$ & $0.46^{f}$ & $0.58^{\mathrm{fg}}$ \\
\hline Eucalyptus 50 mg/l & $0.96^{\mathrm{de}}$ & $1.38^{\text {ef }}$ & $1.72^{\mathrm{e}}$ & $1.06^{\mathrm{e}}$ & $1.51^{d}$ & $1.89^{\mathrm{e}}$ & $0.63^{b}$ & $0.90^{b}$ & $1.13^{\mathrm{abcd}}$ & $0.69^{c d}$ & $0.99^{b}$ & $1.24^{b}$ & $0.33^{\text {ef }}$ & $0.47^{\text {ef }}$ & $0.59^{g h}$ & $0.36^{\mathrm{ef}}$ & $0.51^{\text {ef }}$ & $0.65^{\text {ef }}$ \\
\hline Eucalyptus 75 mg/l & $1.07^{\mathrm{c}}$ & $1.53^{\mathrm{c}}$ & $1.91^{\mathrm{c}}$ & $1.18^{\mathrm{C}}$ & $1.68^{c}$ & $2.10^{\mathrm{c}}$ & $0.70^{\mathrm{a}}$ & $1.00^{\mathrm{a}}$ & $1.26^{\mathrm{ab}}$ & $0.77^{\mathrm{ab}}$ & $1.10^{\mathrm{a}}$ & $1.38^{a}$ & $0.37^{\mathrm{de}}$ & $0.52 \mathrm{de}$ & $0.66^{\mathrm{efg}}$ & $0.40^{\mathrm{de}}$ & $0.57^{\mathrm{de}}$ & $0.72^{\mathrm{de}}$ \\
\hline Mint 25 mg/l & $0.83^{g}$ & $1.18^{\mathrm{h}}$ & $1.47^{\mathrm{j}}$ & $0.90^{\mathrm{h}}$ & $1.29^{f}$ & $1.62^{i}$ & $0.46^{\text {ef }}$ & $0.65^{\mathrm{ef}}$ & $0.82^{\mathrm{fg}}$ & $0.51^{\mathrm{hi}}$ & $0.72^{e f}$ & $0.92^{\mathrm{fg}}$ & $0.35^{\text {def }}$ & $0.51^{\text {def }}$ & $0.65^{\mathrm{fg}}$ & $0.40^{\text {de }}$ & $0.56^{\mathrm{de}}$ & $0.71^{\mathrm{de}}$ \\
\hline Mint 50 mg/l & $0.92^{\text {ef }}$ & $1.31^{\mathrm{fg}}$ & $1.64^{\mathrm{fg}}$ & $1.00^{\text {efg }}$ & $1.34^{\mathrm{de}}$ & $1.80^{\mathrm{fg}}$ & $0.51^{d}$ & $0.73^{d}$ & $0.91^{\text {defg }}$ & $0.56^{g h}$ & $0.80^{d}$ & $1.02^{\mathrm{e}}$ & $0.40^{\mathrm{dc}}$ & $0.57^{\mathrm{cd}}$ & $0.72^{\mathrm{def}}$ & $0.44^{\mathrm{cd}}$ & $0.56^{\mathrm{de}}$ & $0.80^{\mathrm{cd}}$ \\
\hline Mint 75 mg/l & $1.02^{\mathrm{cd}}$ & $1.42^{\mathrm{de}}$ & $1.82^{d}$ & $1.12^{\mathrm{d}}$ & $1.60^{\mathrm{C}}$ & $2.00^{d}$ & $0.57^{\mathrm{c}}$ & $0.81^{\mathrm{c}}$ & $1.02^{\text {cdef }}$ & $0.62^{\text {ef }}$ & $0.90^{\mathrm{C}}$ & $1.13^{\mathrm{C}}$ & $0.45^{\mathrm{bc}}$ & $0.64^{b c}$ & $0.81^{c d}$ & $0.49^{b c}$ & $0.70^{b c}$ & $0.89^{b c}$ \\
\hline $\begin{array}{c}\text { 8-hydroxyqunon } \\
250 \mathrm{mg} / \mathrm{l}\end{array}$ & $1.03^{c}$ & $1.48^{\mathrm{cd}}$ & $1.71^{\mathrm{e}}$ & $0.83^{i}$ & $1.20^{\mathrm{g}}$ & $1.36^{\mathrm{k}}$ & $0.52^{d}$ & $0.75^{d}$ & $0.95^{\text {cdefg }}$ & $0.41^{j}$ & $0.60^{h}$ & $0.78^{h}$ & $0.40^{\mathrm{dc}}$ & $0.57^{\mathrm{cd}}$ & $0.75^{\text {cde }}$ & $0.32^{\mathrm{fg}}$ & $0.58^{\mathrm{de}}$ & $0.59^{f g}$ \\
\hline $\begin{array}{c}\text { 8-hydroxyqunon } \\
300 \mathrm{mg} / \mathrm{l}\end{array}$ & $1.15^{\mathrm{b}}$ & $1.64^{b}$ & $1.90^{\mathrm{c}}$ & $0.92^{h}$ & $1.31^{f}$ & $1.52^{\mathrm{j}}$ & $0.58^{\mathrm{c}}$ & $0.84^{c}$ & $1.35^{\mathrm{a}}$ & $0.52^{\text {ghi }}$ & $0.66^{\mathrm{g}}$ & $0.87^{\mathrm{g}}$ & $0.45^{\mathrm{bc}}$ & $0.64^{b c}$ & $0.84^{b c}$ & $0.35^{\mathrm{ef}}$ & $0.64^{\mathrm{cd}}$ & $0.66^{\mathrm{ef}}$ \\
\hline $\begin{array}{c}\text { 8-hydroxyqunon } \\
350 \mathrm{mg} / \mathrm{l}\end{array}$ & $1.28^{\mathrm{a}}$ & $1.83^{\mathrm{a}}$ & $2.11^{\mathrm{b}}$ & $1.03^{\mathrm{ef}}$ & $1.46^{d}$ & $1.69^{\text {hi }}$ & $0.65^{b}$ & $0.94^{b}$ & $1.17^{\mathrm{abc}}$ & $0.52^{\mathrm{hi}}$ & $0.74^{\mathrm{e}}$ & $0.97^{\mathrm{ef}}$ & $0.50^{\mathrm{ab}}$ & $0.72^{a b}$ & $0.94^{b c}$ & $0.40^{\mathrm{cd}}$ & $0.72^{b c}$ & $0.74^{\mathrm{de}}$ \\
\hline $\begin{array}{c}\text { 8-hydroxyqunon } \\
400 \mathrm{mg} / \mathrm{l}\end{array}$ & $0.93^{\mathrm{e}}$ & $1.33^{\mathrm{efg}}$ & $1.54^{\mathrm{ij}}$ & $0.74^{j}$ & $1.06^{h}$ & $1.22^{1}$ & $0.47^{\mathrm{e}}$ & $0.67^{\mathrm{e}}$ & $0.89^{\text {efg }}$ & $0.37^{j}$ & $0.54^{i}$ & $0.70^{i}$ & $0.36^{\mathrm{de}}$ & $0.52^{\mathrm{de}}$ & $0.67^{\text {efg }}$ & $0.29^{g}$ & $0.52^{e f}$ & $0.54^{\mathrm{g}}$ \\
\hline $\operatorname{LSD}(0.05)$ & 0.07 & 0.10 & 0.06 & 0.06 & 0.09 & 0.07 & 0.03 & 0.05 & 0.23 & 0.06 & 0.05 & 0.07 & 0.06 & 0.09 & 0.10 & 0.06 & 0.10 & 0.11 \\
\hline
\end{tabular}


Table (4). Total soluble solids (TSS \%) and_total carbohydrates (\%) as affected by some chemicals and essential oil extracts on carnation cv. "Big Mama" cultivars during 2017 and 2018 seasons

\begin{tabular}{|c|c|c|c|c|c|c|c|c|c|c|c|c|}
\hline \multirow{3}{*}{ Treatments } & \multicolumn{6}{|c|}{ TSS (\%) } & \multicolumn{6}{|c|}{ Total carbohydrate (\%) } \\
\hline & \multicolumn{3}{|c|}{2017 season } & \multicolumn{3}{|c|}{2018 season } & \multicolumn{3}{|c|}{2017 season } & \multicolumn{3}{|c|}{2018 season } \\
\hline & $5 d$ & $10 d$ & $15 d$ & $5 d$ & 10d & 15d & $5 d$ & $10 d$ & 15d & $5 d$ & $10 \mathrm{~d}$ & 15d \\
\hline Control & $5.43^{i}$ & $6.79 \mathrm{i}$ & $8.48^{h}$ & $5.97^{i}$ & $7.16^{i}$ & $8.59^{9}$ & $4.64^{\mathrm{bc}}$ & $2.96^{\mathrm{e}}$ & $3.71^{\text {ef }}$ & $3.25^{\dagger}$ & $4.07^{\mathrm{cd}}$ & $5.09^{\mathrm{de}}$ \\
\hline Nanc & $6.03^{\mathrm{g}}$ & $7.54 \mathrm{~g}$ & $9.43^{\mathrm{ef}}$ & $6.63^{\mathrm{fgh}}$ & $7.96^{\mathrm{g}}$ & $9.55^{f}$ & $5.15^{\mathrm{bc}}$ & $3.29^{d}$ & $4.12^{d}$ & $3.62^{d}$ & $4.27^{\mathrm{cd}}$ & $5.04^{\mathrm{de}}$ \\
\hline & $6.70^{\mathrm{e}}$ & $8.38 \mathrm{e}$ & $10.47^{d}$ & $7.37^{\mathrm{de}}$ & $8.84^{\mathrm{e}}$ & $10.61^{d}$ & $5.72^{\mathrm{bc}}$ & $3.66^{\mathrm{c}}$ & 4.5 & $4.02^{\mathrm{C}}$ & $4.74^{\mathrm{bc}}$ & $5.60 b$ \\
\hline & $7.45^{\mathrm{c}}$ & $9.31 \mathrm{c}$ & $11.64^{\mathrm{b}}$ & $8.19^{b c}$ & $9.82^{\mathrm{c}}$ & 11.7 & 6.36 & $4.07^{b}$ & & $4.47^{b}$ & 5.2 & $2^{b}$ \\
\hline & $8.28^{a}$ & $10.35 a$ & $12.93^{\mathrm{a}}$ & $9.10^{a}$ & $10.92^{\mathrm{a}}$ & $13.10^{a}$ & $6.84^{\mathrm{ab}}$ & $4.52^{a}$ & & $4.97^{a}$ & & $92^{a}$ \\
\hline & $5.77^{\mathrm{h}}$ & $7.21 \mathrm{~h}$ & $9.02^{\mathrm{fg}}$ & $6.34^{\text {ghi }}$ & $7.61^{\mathrm{h}}$ & $8.83^{g}$ & $4.62^{b c}$ & $2.93^{\mathrm{e}}$ & $7^{\text {ef }}$ & $3.22^{f g}$ & 3.8 & $4.49^{f}$ \\
\hline & $6.41^{f}$ & $8.01 \mathrm{f}$ & $9.78^{\mathrm{e}}$ & $7.05^{\mathrm{ef}}$ & $8.46^{f}$ & $10.15^{\mathrm{e}}$ & $8.47^{a}$ & $3.26^{d}$ & & $3.58^{\mathrm{de}}$ & $4.22^{\mathrm{cd}}$ & $4.98^{\mathrm{de}}$ \\
\hline Euc & $7.12^{d}$ & $8.91 d$ & $11.13^{\mathrm{C}}$ & $7.83^{\mathrm{cd}}$ & $9.40^{d}$ & $11.28^{\mathrm{C}}$ & $5.71^{\mathrm{bc}}$ & $3.62^{c}$ & $4.53^{c}$ & & $4.70^{\mathrm{bc}}$ & $5.54^{c}$ \\
\hline Mint & $5.43^{i}$ & $6.78 \mathrm{i}$ & $8.48^{\mathrm{h}}$ & $6.63^{\mathrm{fgh}}$ & $7.15^{i}$ & $8.58^{\mathrm{g}}$ & $3.99^{c}$ & $2.46^{\mathrm{g}}$ & $3.19^{g}$ & $2.80^{h}$ & $3.30^{e}$ & $3.89^{9}$ \\
\hline & $6.03^{g}$ & $7.53 \mathrm{~g}$ & $9.42^{\mathrm{ef}}$ & $6.63^{\mathrm{fgh}}$ & $7.95^{\mathrm{g}}$ & $9.54^{f}$ & $4.43^{b c}$ & $2.73^{f}$ & $3.54^{f}$ & $3.11^{\mathrm{g}}$ & $3.67^{\mathrm{de}}$ & $4.33^{f}$ \\
\hline Min & $6.70^{\mathrm{e}}$ & $8.37 \mathrm{e}$ & $10.47^{d}$ & $7.36^{\mathrm{de}}$ & $8.83^{\mathrm{e}}$ & $10.60^{d}$ & $4.93^{b c}$ & $3.15^{\mathrm{d}}$ & & $3.46^{\mathrm{e}}$ & $4.08^{\mathrm{cd}}$ & $4.82^{\mathrm{e}}$ \\
\hline droxy & $5.61^{\mathrm{hi}}$ & 7.02hi & $8.77^{\text {gh }}$ & $6.85^{\mathrm{efg}}$ & $8.23^{\mathrm{fg}}$ & & $4.57^{\mathrm{bc}}$ & $2.92^{\mathrm{e}}$ & & $3.56^{\mathrm{de}}$ & $3.20^{\mathrm{e}}$ & $4.96^{\mathrm{de}}$ \\
\hline droxy & $6.24^{\mathrm{fg}}$ & $7.79 \mathrm{fg}$ & $9.75^{\mathrm{e}}$ & $7.62^{d}$ & $9.14^{\mathrm{de}}$ & $10.64^{d}$ & $5.07^{\mathrm{bc}}$ & $3.25^{\mathrm{d}}$ & & $3.96^{c}$ & $4.67^{b c}$ & $5.18^{d}$ \\
\hline droxyqun & $7.70^{b}$ & $9.63 b$ & $12.03^{b}$ & $8.47^{b}$ & $10.16^{b}$ & $12.20^{b}$ & $6.27^{\mathrm{abc}}$ & $4.01^{b}$ & & & $5.20^{\mathrm{ab}}$ & $5.60 b$ \\
\hline - & $6.93^{\mathrm{de}}$ & 8.66de & $10.83^{\mathrm{cd}}$ & $6.17^{\text {hi }}$ & $7.41^{\mathrm{hi}}$ & $8.89^{\mathrm{g}}$ & $5.64^{\mathrm{bc}}$ & $3.60^{\mathrm{C}}$ & & $3.21^{\mathrm{fg}}$ & $3.78^{\mathrm{de}}$ & $4.47^{f}$ \\
\hline $\operatorname{LSD}(0.05)$ & 0.24 & 0.30 & 0.44 & 0.54 & 0.33 & 0.43 & 2.50 & 0.16 & 0.27 & 0.13 & 0.76 & 0.29 \\
\hline
\end{tabular}




\section{CONCLUSION}

In conclusion, the present study demonstrates that flowers treated with $10 \mathrm{mg} / \mathrm{l}$ nano silver significantly increased total dry weight, vase life, florte diameter, total sugars $(\%)$, reducing sugars $(\%)$, non-reducing sugars $(\%)$, TSS $(\%)$, total carbohydrates (\%) and decrease number of bacteria as compared with control treatment which gave the lowest mean values of the all physical and chemical composition during both experiments.

\section{REFERENCES}

Ardebili, O. Z., V. Abdossi, R. Zargarani and N. O. Ardebili (2013). The promoted longevity of gerbera cut flowers using geranyl diphosphate and its analog. Turk J. Agric. For., 37: 45-51.

Banaee, S., E. Hadavi and P. Moradi (2013). Interaction effect of sucrose, salicylic acid and 8- hydroxyquinoline sulfate on vase-life of cut gerbera flowers. Curr. Agric. Res. J., 1(1): 39-43.

Basiri, Y., H. Zarei and K. Mashayekhi (2011). Effects of Nano-Silver Treatments on Vase Life of Cut Flowers of Carnation (Dianthus caryophyllus CV. 'White Librity'). J. Adv. Lab. Res. Biol., 2(2): 49-55.

Danaee, E., R. Naderi, S. Kalatejari, A. Reza and L. Moghadam (2013). Evaluation the effect of nanosilver with salicylic acid and benzyladenine on longevity of gerbera flowers. J. Basic. Appl. Sci. Res., 3(8): 682-690.

Dashtbany, S. and D. Hashemabadi (2015). Study on interaction effects of mechanical and Geranium essential oil treatments on vase life of cut Chrysanthemum (Dendranthema grandiflorum L.).J. Orn. Pla., 5 (2): 97-103.

De Witte, Y., H. Harkema and van W. G. Doorn (2014). Effect of antimicrobial compounds on cut Gerbera flowers: Poor relation between stem bending and numbers of bacteria in the vase water. Postharvest Biol. \& Tech., 91: 78-83.

Dubios, M., K. Gilles, J.K. Hamilton, P. A. Rebers and F. Smith (1956). Phenol sulphuric acid calorimetric estimation of carbohydrates. Annal. Chem., 28(3): 350-356.

Ebrahimzadeh, A., M. B. Hassanpouraghdam, F. Hashemi Hajikandi, M. A. Aazami Mavaloo and L. V. Mehrabani (2017). Substitution of silverthiosulfate (STS) with some essential oils on vase-life of cut carnation cv. liberty. Trakia J. Sci., (1): 20-26

Elgimabi, M.N.E.E. (2014). Pulsing with sucrose and silver nitrate enhance water uptake and result in along vase life in Taif rose cut flowers (Rosa damascena cv. Trigintipetala). Intl. J. Agric. Sci., 6(1): 379-383.

Furno, F., K.S. Morley, W. B. Sharp, P.L. Arnold, S.M. Howdle, R. Bayston, P.D. Brown, P.D. Winship and H.J. Reid (2004). Silver nanoparticles and polymeric medical devices, a new approach to prevention of infection. J. Antimicrob. Chemother., 54: 1019-1024.

Gomez, A. K. and A. A. Gomez (1984). Statistical procedures for Agricultural Research. ( $2^{\text {nd }}$ edition). John Wiley and Sons. New York. 
Gorin, N., G. L. Staby, W. Klap, N. Tipper and D.L. Luvssing (1989). Quality measurements of carnation treatment solutions in relation to flower silver distribution and longevity. J. Hort. Sci., 110(5): 117-12

Hashemabadi, D. (2014). The role of silver nano-particles and silver thiosulfate on the longevity of cut carnation (Dianthus caryophyllus) flowers. J. Environ. Biol., 35(4): 661-666.

Hashemabadi, D., B. Kaviani, A. Shirinpour and D. Yaghoobi (2015). Response of cut carnation (Dianthus caryophllus, L. cv. Tempo) to essential oils and antimicrobial compounds. Int. J. Biosci., 6(3): 36-44.

Hatami, M., A. Hatamzadeh, M. Ghasemnezhad and M. Ghorbanpour (2013). The comparison of antimicrobial effects of silver nanoparticles and silver nitrate to extend the vase life or 'red ribbon' rose cut flowers. Trakia J. Sci., 2: 144-151.

Ibrahim, S. M.M., L.S. Taha and R. A. Eid (2011). Extending postharvest life and keeping quality of gerbera cut flowers using some chemical preservatives. J. Appl. Sci. Res., 7(7): 1233-1239.

Ichimura, K., Y. Kawabata, M. Kishimito, R. Goto and K. Yamada (2002). Variation with the cultivar in the vase life of cut rose flowers. Bull. Natl. Inst. Flor. Sci., 2: 9-20.

Karimi, L., A. Aboutalebi and M. Jaffarpoor (2011). The effect herbal essences on vase life cut rose. The sixth congress of new ideas in agriculture, Iran, 323324.

Kazemi, M., S. Zamani and M. Aran (2011). Effect of some treatment chemicals on keeping quality and vase-life of cut flowers. Am. J. Plant Physiol., 6: 99-105.

Khosravi, N. L., N. Rood, A. Danyaei, and M. Babarabie (2015). The Effect of Eucalyptus and Rosa damascena essences with sucrose on vase life and physiological characteristics of cut Gerbera cv. 'Alain Ducasse'. J. Ornam. Plants, 5 (4): 205-212.

Lacey, L., A. M. Carthy and G. Foord (2001). Maturity testing of citrus. Farmnote. Dep. Agri. West. Australia, 3:1-5.

Liu, J. P., S.G. He, Z.Q. Zhang, J. P. Cao, P.T. Lv, S.D. He, G.P. Cheng and D.C. Joyce, (2009). Nanosilver pulse treatments inhibit stem-end bacteria on cut gerbera cv. "Ruikou" flowers. Postharvest Biol. Tech., 54(1): 59-62.

Lü, P., S. He, H. Li, J. Cao and H. Xu (2010). Effects of nano-silver treatment on vase life of cut rose cv. Movie Star flowers. J. Food Agric. Environ., 8 (2): 1118 $-1122$.

Lv, P., S. He., H. Li., J. Cao and H. Xu (2010). Effect of nano silver treatment on vase life of cut rose cv. Movie Star flowers. J. Food Agric. Environ., 8: 11181122.

Malik, C. P. and M. B. Singh (1980). Plant Enzology and Histo-Enzology. A. Text manual. Kalayani Puplishers New Delhi. India, 276-277.

Mir Saeed Ghazi, M.A., R. Naderi, and S. K. Jari (2013). Investigate on effect of nanoparticles of titanium, nanosilver and some essential oils on the longevity and quality of cut flowers Alstroemeria. Plants \& Ecol., 9(37): 85-99.

Moon-Soo, C., G. C. Fisun, D. Linda and S. R. Michael (2001). Sucrose enhances the postharvest quality of cut flowers of Eustoma grandiflorum (raf.) shinn. In: Nell, T.A., Clark, D.G. (Eds.), Proceedings of the VII International Symposium on Postharvest Physiology Ornamentals. Acta Horti., 543, ISHS.

Moradi, P., H. Afshari and A. G. Ebadi (2012). The effect of benzyl adenine, nano silver, 8-hydroxylquinolin sulfate, and sucrose on longevity improvement and 
some other quality characteristics of Dianthus cv. "Cream Viana" cut flower. Ind. J. Sci. Technol., 5:2459-2463.

Prashanth, P., R. C. Sekhar, K. Chandra and S. Reddy (2010). Influence of floral preservatives on scape bending, biochemical changes and post-harvest vase life of cut gerbera (Gerbera jamesonii bolus ex. Hook.). Asian J. Hort., 5: 1-6.

Pun, U.K. and K. Ichimura (2003). Role of sugars in senescence and biosynthesis of ethylene in cut flowers. JARQ 4: 219-224.

Roshani, T., N. Ahmadi and G. Karimzadeh (2016). Effects of silver nano particles and 1-MCP on postharvest characteristic and activities of enzymes involved in cut carnation flower senescence. Adv. Appl. Sci., 1-10.

Sharififar, F., M.H. Moshafi, S.H. Mansouri, M. Khodashenas and $M$. Khoshnoodi (2007). In vitro evaluation of antibacterial and antioxidant activities of the essential oil and methanol extract of endemic Zataria multiflora Boiss. Food Control, 18: 800-805.

Sharma, N. and A. Tripathi (2008). Effects of Citrus sinensis (L.) Osbeck epicarp essential oil on growth and morphogenesis of Aspergillus niger (L.) Van Tieghem. Microbiol. Res., 163: 337-344.

Sharma, R., R. Srivastava and S. Bhardwaj (2013). Studies on genetic divergence in carnation (Dianthus caryophyllus, L.) Annuals of Agri-Bio Res.., 18(2): 219222.

Solgi, M., M. Kafi, T.S. Taghavi and R. Naderi (2009). Essential oils and silver nanoparticles (SNP) as novel agents to extend vase-life of gerbera (Gerbera jamesonii cv. 'Dune') flowers. Postharvest Biol. Technol., 53: 155-158.

Solgi, M. (2014). Evaluation of plant-mediated silver nanoparticles synthesis and its application in postharvest physiology of cut flowers. Physiol. Mol. Biol. Plants., 20(3):279-285.

Svircev, A.M., R.J. Smith, T. Zhou, M. Hernade, W. Liu and C.L. Chud (2007). Effects of thymol fumigation on survival and ultrastracture of Monilinia fructicola. Postharvest Biol. Technol., 45: 228-233.

Tanase, K., C. Nishitani, H. Hirakawa, S. Isobe, S. Tabata, A. Ohmiya and T. Onozaki (2012). Transcriptome analysis of carnation (Dianthus caryophyllus, L.) based on next-generation sequencing technology. BMC Genomics., 13: 292.

Van Doorn, W.G. (2004). Is petal senescence due to sugar starvation. Plant Physiol., 134: 35-42.

Wu, H.J., J. Henzie, W.C. Lin, C. Rhodes, Z. Li, E. Sartorel, J. Thorner, P. Yang and J. T. Groves (2012). Membrane-protein binding measured with solutionphase plasmonic nanocube sensors. Nat. Methods, 9(12): 1189-1191. 
الملخص العربي

تأثير بعض المواد الكيماوية ومستخلصات الزيوت العطرية علي القدرة الحفظية وعمر أزهار القزنقل المقطوفة

(') ثناء مصطفى عز (r) بثينه محمد وحياه (') محمد قرى (r) هناء فوزي قطب الايب

(') قسم الإنتاج النباتي - كلية الزراعة (سابا باشا)- جامعة الإسكندرية

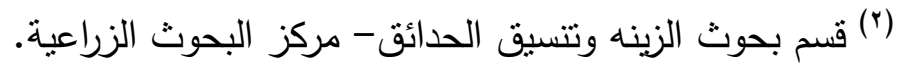

(ץ) باحث زراعي أول- مركز البحوث الزراعية

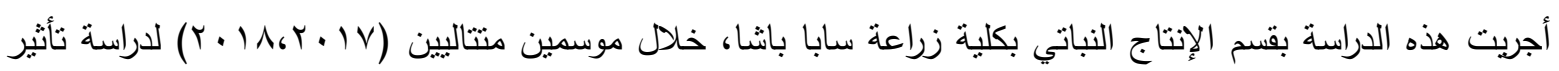

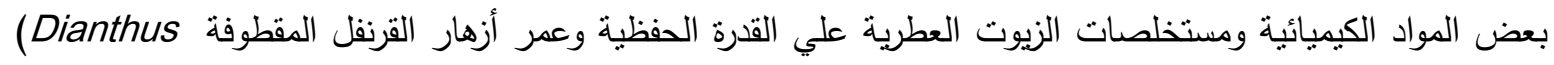
caryophyllus, L. cv. "Big Mama")

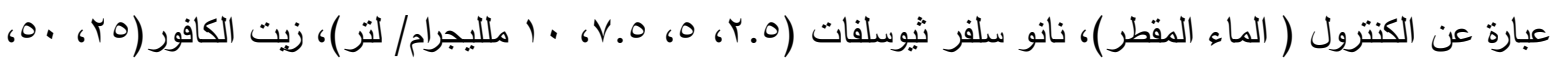

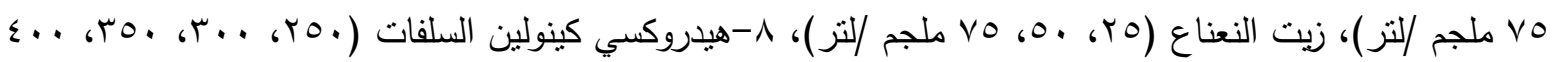

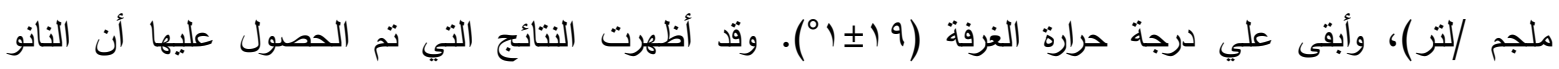
سلفرثيوسلفات بمعدل • ا مجم/ لتز سجل أفضل النتائج حيث أعطي أعلي منوسط قيم لكل من الصفات الفيزيائية منل الوزن الجاف، فترة حباة الزهرة، قطر الزهرة واقل عدد للبكتريا، وكذلك أعلى القيم للصفات الكيميائية مثل السكريات الكلية

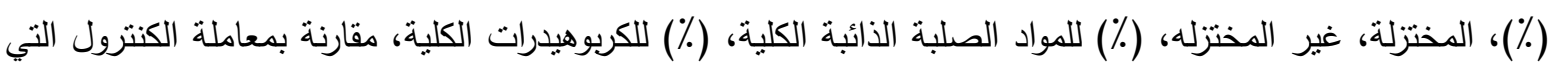

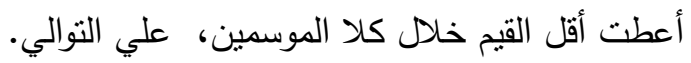

